\title{
Uczeni, poeci i inni - bibliotekarze bibliotek prywatnych (książąt, hrabiów, baronów) na ziemiach niemieckich w XIX wieku
}

Pierwsze biblioteki prywatne na ziemiach niemieckich powstawały już w XV i XVI w. Zakładane były w pierwszej kolejności na dworach królewskich, książęcych, hrabiowskich i biskupich. Wiek XVII przyniósł znaczny wzrost liczby tego typu księgozbiorów, zwłaszcza po ustaniu wojen religijnych, gdy w drugiej połowie stulecia nastąpił dalszy rozwój, aby w następnym wieku - zwanym le siècle des Lumières - miał miejsce prawdziwy rozkwit bibliotek. Pośród tych książęcych wyróżniały się zarówno wielkością, jak i zawartością kolekcje księcia von Ratibor w Korvey (Corvey) ${ }^{1}$, biblioteka dworska w Donaueschingen ${ }^{2}$ oraz biblioteka książęca w Maihingen ${ }^{3}$. Najznakomitsze księgozbiory należały m.in. do hrabiego Heinricha von Bünau (liczący 42000 tomów $)^{4}$ i hrabiego Heinricha von Brühl w Dreźnie (62 000 tomów) ${ }^{5}$. Spore księgozbiory były też własnością burmistrzów, np. Zachariasa Conrada Uffenbacha we Frankfurcie nad Menem (40 000 tytułów) ${ }^{6}$, czy lekarzy np. Johanna Christiana Senckeberga (40 000 tomów i 130000 dysertacji) ${ }^{7}$. Motywy zakładania bibliotek w Niemczech przez prywatne osoby czy instytucje były różne. Nie można wykluczyć nawet snobizmu czy mody, ale wśród głównych powodów znajdowały się: umiłowanie ksiąg, pasje kolekcjonerskie czy też tradycje bibliofilskie. Ernest Mehl i Kurt Hannemann podają, że między 1700 a 1740 r. istniało w Niemczech około 180 księgozbiorów prywatnych ${ }^{8}$.

\footnotetext{
Zob. P. Schwenke, Adressbuch der deutschen Bibliotheken, Leipzig 1893, s. 465.

Zob. tamże, s. 339.

Zob. tamże, s. 492.

Zob. tamże, s. 341.

Zob. J. Vorstius, S. Joost, Grundzüge der Bibliotheksgeschichte, Wiesbaden 1980, s. 48-49.

6 Zob. J. Petzholdt, Adressbuch der Bibliotheken Deutschlands mit Einschluss von Österreich und der Schweiz, Dresden 1875, s. 135-137.

Zob. tamże, s. 135-136.

8 Zob. E. Mehl, K. Hannemann, Deutsche Bibliotheksgeschichte, Berlin 1969, s. 58. Zob. też
} A. Żbikowska-Migoń, Dzieje ksiązki i jej funkcji społecznej. Wiek XVIII, Wrocław 1987, s. 103-109. 
Wiek XIX, a przynajmniej jego dwie pierwsze dekady, kiedy to wojny przetoczyły się przez ziemie niemieckie, nie był zbyt łaskawy dla tamtejszych bibliotek prywatnych. Dopiero demokratyzacja życia politycznego i społecznego po 1848 r., przejawiająca się m.in. w szerszym otwarciu dla publiczności wielu bibliotek dworskich i miejskich, oraz zakładanie bibliotek stowarzyszeniowych i publicznych sprawiły, że biblioteki prywatne stały się $\mathrm{w}$ pewnym stopniu reliktem, ale $\mathrm{z}$ drugiej strony $-\mathrm{z}$ uwagi na niezmiernie cenne księgozbiory - stanowiły niezmiernie ważny element ówczesnego krajobrazu bibliotecznego, a dla uczonych, literatów i bibliofilów - często obowiązkowy warsztat ich pracy. Wciąż jednak spełniały bowiem istotną rolę i wypełniały lukę, która nastąpiła po likwidacji - w wyniku sekularyzacji - księgozbiorów klasztornych. Mowa tu przede wszystkim o bibliotekach będących w posiadaniu królów, książąt, książąt elektorów i hrabiów. Do tych bibliotek właśnie ograniczono analizę. Wykaz bibliotek prywatnych na ziemiach niemieckich w XIX stuleciu sporządzony na podstawie księgi adresowej Juliusa Petzholdta ${ }^{9}$ i leksykonu niemieckich bibliotekarzy Karla Badera ${ }^{10}$ rejestruje ogółem 25 bibliotek prywatnych. Podobne zestawienie przygotowane na podstawie księgi adresowej Paula Schwenkego (1853-1921) odnotowuje już 58 bibliotek tego typu ${ }^{11}$. Do tego trzeba dodać wykaz bibliotek należących do książąt i hrabiów Niemiec i Austrii dr. Wilhelma Gröplera ${ }^{12}$ (zob. Tabela 1). Wiadomo, że każdy z rejestrów jest niekompletny, co wynika poniekąd z metody zastosowanej przy ich tworzeniu, czyli przejmowaniu opisów z drugiej ręki, tj. z dostępnych opracowań i/lub informacji przesłanych przez organizatorów bibliotek. Większość ich opisów jest ograniczonych do kilku wierszy, w których zawarte są podstawowe dane o profilu księgozbioru, jego wielkości, osobach nim zarządzających oraz o katalogach. Wyjątek potwierdzający tę regułę stanowią obszerniejsze, nawet kilkustronicowe hasła poświęcone wielkim bibliotekom dworskim, królewskim i książęcym m.in. w Berlinie, Monachium i Dreźnie. Jest to jednak w tej chwili częstokroć jedyne wiarygodne źródło informacji w niemieckiej literaturze przedmiotu.

\footnotetext{
9 Zob. J. Petzholdt, Adressbuch der Bibliotheken Deutschlands...

10 Zob. K. Bader, Lexikon Deutscher Bibliothekare im Haupt- und Nebenamt bei Fürsten, Staaten und Städten, Leipzig 1925.

11 Zob. P. Schwenke, dz. cyt.

12 Zob. W. Gröpler, Büchereien mittelbarer Fürsten und Grafen Deutschlands und Österreichs sowie ehemaliger Freien Deutschen Reichsstädte, Dessau-Leipzig 1891.
} 
Uczeni, poeci i inni - bibliotekarze bibliotek prywatnych (książąt, hrabiów, baronów)...

Tabela 1. Biblioteki prywatne na ziemiach niemieckich w XIX w. Stan księgozbioru

\begin{tabular}{|c|c|c|c|}
\hline Lp. & Nazwa biblioteki & $\begin{array}{c}\text { Data } \\
\text { założenia }\end{array}$ & $\begin{array}{l}\text { Wielkość } \\
\text { księgozbioru } \\
\text { (liczba tomów) }\end{array}$ \\
\hline 1. & $\begin{array}{l}\text { Fürstlich Hohenlohe-Bartenstein'sche, } \\
\text { Bartenstein, Wirtembergia }\end{array}$ & XVIII w. & 4000 \\
\hline 2. & $\begin{array}{l}\text { Fürstliche Isenburg-Birstein’sche } \\
\text { Bibliothek, Birstein, Hesja-Nassau }\end{array}$ & brak danych & ok. 25000 \\
\hline 3. & $\begin{array}{l}\text { Fürstliche Isenburgische } \\
\text { Schlossbibliothek, Büdingen, Hesja }\end{array}$ & XVI w. & ok. 20000 \\
\hline 4. & $\begin{array}{l}\text { Gräflich von Schweinitz'sche } \\
\text { Majoratsbibliothek, Dieban (Dziewin) } \\
\text { k. Steinau (Ścinawy), Śląsk }\end{array}$ & $\begin{array}{l}\text { II poł. } \\
\text { XVIII w. }\end{array}$ & 7859 \\
\hline 5. & $\begin{array}{l}\text { Fürstlich Fürstenbergische Hofbibliothek, } \\
\text { Donaueschingen, Badenia }\end{array}$ & przed $1500 \mathrm{r}$. & ok. 100000 \\
\hline 6. & $\begin{array}{l}\text { Privatbibliothek Sr. Maj. des Königl } \\
\text { Albert, Drezno, Saksonia }\end{array}$ & brak danych & ok. 50000 \\
\hline 7. & $\begin{array}{l}\text { Priznzliche Sekundogeniturbibliothek, } \\
\text { Drezno, Saksonia }\end{array}$ & $1767 \mathrm{r}$. & ok. 60000 \\
\hline 8. & $\begin{array}{l}\text { Gräfliche Erbach-Fürstenau'sche } \\
\text { Bibliothek, Fuerstenau bei Michelstadt, } \\
\text { Hesja }\end{array}$ & pocz. XIX w. & ok. 8000 \\
\hline 9. & $\begin{array}{l}\text { Reichsgräflich Schaffgotsch’sche } \\
\text { Bibliothek, Książ, Śląsk }\end{array}$ & $1709 \mathrm{r}$. & $\begin{array}{l}\text { ponad } \\
60000\end{array}$ \\
\hline 10. & $\begin{array}{l}\text { Reichsgräflich von Hochberg'sche } \\
\text { Majorats-Bibliothek, Fuerstenstein } \\
\text { (Książ), Śląsk }\end{array}$ & ok. $1600 \mathrm{r}$. & ok. 37000 \\
\hline 11. & $\begin{array}{l}\text { Fürstliche Reuss Schlossbibliothek, } \\
\text { Gera, Reuss }\end{array}$ & XVIII w. & ok. 1500 \\
\hline 12. & $\begin{array}{l}\text { Gräflich Oppersdorf’sche Bibliothek, } \\
\text { Głogówek, Sląsk }\end{array}$ & XVI/XVII w. & 2400 \\
\hline 13. & $\begin{array}{l}\text { Gräflich von Mirbach'sche Fideikomiss- } \\
\text { Bibliothek, Harff, Nadrenia }\end{array}$ & XVI w. & ok. 15000 \\
\hline 14. & $\begin{array}{l}\text { Fürstlich Karolath-Beuthener } \\
\text { Majoratsbibliothek, Carolath (Siedlisko), } \\
\text { Śląsk }\end{array}$ & XVI w. & 6470 \\
\hline 15. & $\begin{array}{l}\text { Fürstliche Bibliothek, Korvey, Biblioteka } \\
\text { prywatna Księcia von Ratibor, Westfalia }\end{array}$ & $1826 \mathrm{r}$. & ok. 180000 \\
\hline 16. & $\begin{array}{l}\text { Gräflich Wallenrodt’sche Bibliothek, } \\
\text { Królewiec, Prusy }\end{array}$ & $1629 \mathrm{r}$. & ok. 10000 \\
\hline
\end{tabular}




\begin{tabular}{|c|l|l|l|}
\hline 17. & $\begin{array}{l}\text { Herzogliche (Schloss-)Bibliothek, } \\
\text { Koethen, Anhalt }\end{array}$ & 1655 r. & ok. 18000 \\
\hline 18. & $\begin{array}{l}\text { Bibliotheca Carlowitziana, Kukukstein } \\
\text { k. Liebstadt, Saksonia }\end{array}$ & poł. XVIII w. & ok. 8200 \\
\hline 19. & $\begin{array}{l}\text { Gräflich Solms-Laubachische Bibliothek, } \\
\text { Laubach, Hesja }\end{array}$ & 1680 r. & ok. 38000 \\
\hline 20. & $\begin{array}{l}\text { Schlossbibliothek, Nieder-Schoenbrunn, } \\
\text { Lauban (Lubań), Sląsk }\end{array}$ & 1821 r. & ok. 11000 \\
\hline 21. & $\begin{array}{l}\text { Reichsgräflich von Wolkenstein- } \\
\text { Nostiz'sche Bibliothek, Lobris } \\
\text { (Luboradz) k. Jawora, Sląsk }\end{array}$ & 1682 r. & ok. 10500 \\
\hline 22. & $\begin{array}{l}\text { Fürstliche Oettingen-Wallerstein'sche } \\
\text { Fideikomissbibliothek, Maihingen, } \\
\text { Bawaria }\end{array}$ & 1670 r. & 99927 \\
\hline 23. & $\begin{array}{l}\text { Schlossbibliothek, Nieder-Schoenbrunn } \\
\text { (Studniska Dolne), Slląsk }\end{array}$ & poł. XVI w. & ok. 11000 \\
\hline 24. & $\begin{array}{l}\text { Gräflich Esterházy'sche Schlossbibliothek, } \\
\text { Nordkirchen, Westfalia }\end{array}$ & 1691 r. & 7051 \\
\hline 25. & $\begin{array}{l}\text { Fürstlich Wiedische Bibliothek, } \\
\text { Noerdlingen, Bawaria }\end{array}$ & brak danych & ok. 4000 \\
\hline 26. & $\begin{array}{l}\text { Gräflich von Fürstenbergische } \\
\text { Bibliothek, Oberhundem, Westfalia }\end{array}$ & $1662 / 1718$ r. ${ }^{13}$ & ok. 30000 \\
\hline 27. & $\begin{array}{l}\text { Grossherzogliche Privatbibliothek, } \\
\text { Oldenburg }\end{array}$ & 1783 r. & ok. 55000 \\
\hline 28. & $\begin{array}{l}\text { Freiherrlich von Oldershausen'sche Ma- } \\
\text { joratsbibliothek, Oldershausen, Hanower }\end{array}$ & XVIII w. & ok. 6000 \\
\hline 29. & $\begin{array}{l}\text { Fürstlich Hohenlohe'sche Bibliothek, } \\
\text { Oppurg, Saksonia-Weimar }\end{array}$ & 1769 r. & ok. 1800 \\
\hline 30. & $\begin{array}{l}\text { Gräflich Schönborn-Wiesentheid'sche } \\
\text { Bibliothek, Pommersfelden, Bawaria }\end{array}$ & 1729 r. & 7955 \\
\hline 31. & $\begin{array}{l}\text { Schlossbibliothek, Pless (Pszczyna), } \\
\text { Sląsk }\end{array}$ & brak danych & ok. 3000 \\
\hline 32. & $\begin{array}{l}\text { Gräflich Baudissin'sche } \\
\text { Fideikommissbibliothek, Rantzau, } \\
\text { Szlezwik-Holsztyn }\end{array}$ & 1751 r. & ok. 4000 \\
\hline 33. & $\begin{array}{l}\text { Fürstlich Thurn- und Taxis'sche } \\
\text { Hofbibliothek, Regensburg, Bawaria }\end{array}$ & 1770 r. & ok. 50000 \\
\hline 34. & $\begin{array}{l}\text { Freiherrlich Schenk von } \\
\text { Risstissen, Wirtembergia }\end{array}$ & brak danych & 10700 \\
\hline
\end{tabular}

13 Są to lata narodzin i śmierci właściciela, Ferdinanda von Fürstenberga - zob. P. Schwenke, dz. cyt., s. 284-285. 
Uczeni, poeci i inni - bibliotekarze bibliotek prywatnych (książąt, hrabiów, baronów)...

\begin{tabular}{|c|c|c|c|}
\hline 35. & $\begin{array}{l}\text { Freiherrlich von Friesen'sche } \\
\text { Familienbibliothek, Roetha, Saksonia }\end{array}$ & $1580 \mathrm{r}$. & ok. 15000 \\
\hline 36. & $\begin{array}{l}\text { Gräflich Stolbergische Hausbibliothek, } \\
\text { Rossla, Saksonia }\end{array}$ & $\begin{array}{l}\text { pocz. } \\
\text { XVIII w. }\end{array}$ & ok. 17000 \\
\hline 37. & $\begin{array}{l}\text { Reichsgräflich Grote'sche } \\
\text { Fideikommissbibliothek, Schauen, } \\
\text { Saksonia }\end{array}$ & $1753 \mathrm{r}$. & ok. 8000 \\
\hline 38. & $\begin{array}{l}\text { Schlossbibliothek, Schillingsfürst, } \\
\text { Bawaria }\end{array}$ & $1859 \mathrm{r}$. & ok. 5000 \\
\hline 39. & $\begin{array}{l}\text { Herrschaftliche von Zehmen'sche } \\
\text { Bibliothek, Schleinitz, Saksonia }\end{array}$ & $1680 / 1742 r^{14}$ & ok. 4000 \\
\hline 40. & $\begin{array}{l}\text { Gräflich Erbach-Schönberg'sche } \\
\text { Familienbibliothek, Schoenberg, Hesja }\end{array}$ & poł. XVIII w. & ok. 7000 \\
\hline 41. & $\begin{array}{l}\text { Fürstliche Hohenzollerische } \\
\text { Hofbibliothek, Sigmaringen, Prusy }\end{array}$ & $1811 / 1885 \mathrm{r}^{15}$ & 29500 \\
\hline 42. & $\begin{array}{l}\text { Freiherrlich von Landsberg'sche } \\
\text { Bibliothek, Steinfurt, Westfalia }\end{array}$ & $\begin{array}{l}\text { II poł. } \\
\text { XVIII w. }\end{array}$ & brak danych \\
\hline 43. & $\begin{array}{l}\text { Gräflich Stolberg-Stolberg'sche } \\
\text { Bibliothek, Stolberg, Saksonia }\end{array}$ & brak danych & $\begin{array}{l}\text { ok. } 20000 \\
\text { sztuk }^{16}\end{array}$ \\
\hline 44. & $\begin{array}{l}\text { Königliche Handbibliothek, Stuttgart, } \\
\text { Wirtembergia }^{17}\end{array}$ & $1810 \mathrm{r}$. & ok. 120000 \\
\hline 45. & $\begin{array}{l}\text { Gräflich Giesch'sche Bibliothek, } \\
\text { Thurnau, Bawaria }\end{array}$ & $1770 \mathrm{r}$. & ok. 30000 \\
\hline 46. & $\begin{array}{l}\text { Fürstlich Löwenstein-Wertheim-Freuden- } \\
\text { bergische Bibliothek, Triefenstein, Bawaria }\end{array}$ & brak danych & brak danych \\
\hline 47. & $\begin{array}{l}\text { Freiherrlich von Wolff-Metternich'sche } \\
\text { Bibliothek, Wehrden, Badenia }\end{array}$ & $1694 \mathrm{r}$. & ok. 3800 \\
\hline 48. & $\begin{array}{l}\text { Fürstlich Stolberg-Wernigerödische } \\
\text { Bibliothek, Wernigerode, Saksonia }\end{array}$ & $1570 \mathrm{r}$. & 102000 \\
\hline 49. & $\begin{array}{l}\text { Fürstlich Löwenstein-Wertheim-Rosen- } \\
\text { bergische Domänenkanzlei-Bibliothek, } \\
\text { Wertheim, Badenia }\end{array}$ & $1803 \mathrm{r}$. & ok. 5500 \\
\hline 50. & $\begin{array}{l}\text { Königliche Schlossbibliothek, } \\
\text { Wilhelmshoehe, Hesja-Nassau }\end{array}$ & $1799 \mathrm{r}$. & ok. 14500 \\
\hline 51. & $\begin{array}{l}\text { Förstlich Waldburg-Wolfegg- } \\
\text { Waldsee'sche Bibliothek, Wolfegg, } \\
\text { Wirtembergia }\end{array}$ & $1606 \mathrm{r}$. & ok. 12000 \\
\hline
\end{tabular}

14 Są to lata narodzin i śmierci założyciela biblioteki Joachima Dietricha von Rose - zob. tamże, s. 318.

15 Są to lata narodzin i śmierci założyciela biblioteki - zob. tamże, s. 325-326.

16 Zob. tamże, s. 335.

17 Biblioteka prywatna króla Karla, znajdująca się w tym samym gmachu co Królewska Biblioteka Dworska - zob. tamże, s. 342. 


\begin{tabular}{|l|l|l|l|}
\hline 52. & $\begin{array}{l}\text { Fürstliche Bibliothek, Wurzach, } \\
\text { Wirtembergia }\end{array}$ & brak danych & ok. 6000 \\
\hline 53. & $\begin{array}{l}\text { Von Brand-Wutzig-Hermsdorf'sche Fa- } \\
\text { milien-Fideikommissbibliothek, Wutzig, } \\
\text { Brandenburgia }\end{array}$ & brak danych & 4846 \\
\hline 54. & $\begin{array}{l}\text { Fürstlich Waldburg-Zeil-Trauchburg'sche } \\
\text { Fideikommissbibliothek, Zeil, Wirtembergia }\end{array}$ & 1750 r. & ok. 13000 \\
\hline 55. & Schlossbibliothek, Sagan (Żagań), Śląsk & koniec XVIII w. & ok. 10000 \\
\hline
\end{tabular}

Źródło: J. Petzholdt, Adressbuch der Bibliotheken Deutschlands mit Einschluss Österreich und der Schweiz, Dresden 1875; P. Schwenke, Adressbuch der deutschen Bibliotheken, Leipzig 1893; W. Gröpler, Büchereien mittelbarer Fürsten und Grafen Deutschlands und Österreichs sowie ehemaliger freien Deutschen Reichsstädte, Leipzig 1891.

Omawiane w artykule typy bibliotek prywatnych na ziemiach niemieckich były bardzo zróżnicowane, od wielkości poczynając, poprzez profil gromadzenia, a na udostępnianiu kończąc. Księgozbiory, co pokazuje Tabela 1, niekiedy liczyły zaledwie kilkaset tomów, częściej sięgały kilku i kilkunastu tysięcy, wyjątkowo dochodziły do kilkudziesięciu tysięcy woluminów. Przykładem najznaczniejszych bibliotek prywatnych są księgozbiory w Korvey, Dreźnie, Oldenburgu i w Ratyzbonie. Na przykład istniejąca już od 1709 r., a od 1834 r. mieszcząca się w Cieplicach, Biblioteka Ordynacji Schaffgotschów liczyła 80000 tomów $^{18}$. O wielkości i zawartości księgozbioru przesądzały możliwości finansowe posiadacza. Wśród bibliotek o niskim, nieregularnym budżecie przeważały te należące do osób z tytułem hrabiowskim. Czynnik różnicujący biblioteki prywatne to także ich profil. $Z$ reguły były to kolekcje gromadzące dzieła humanistyczne, z ukierunkowaniem na literaturę i historię. W strukturze księgozbiorów zauważalne są też takie dziedziny jak prawo i teologia, a w niektórych bibliotekach - dyscypliny czysto praktyczne, jak rolnictwo i leśnictwo (Noerdlingen, Steinfurt). Profil ogólny, czyli uwzględnianie w procesie gromadzenia wszystkich dziedzin wiedzy, spotykany jest tylko w nielicznych bibliotekach, np. w Liebstein, Thurnau i Ratyzbonie. Nawiasem mówiąc, o wartości księgozbiorów nie decydowała li tylko wielkość biblioteki czy profil, lecz częstokroć - proweniencja zbiorów. Wiele z nich zawierało pozycje przejęte $\mathrm{z}$ bibliotek klasztornych po ich sekularyzacji. Niemało z nich posiadało rękopisy i inkunabuły (Fürstenstein, Oberhundem). Prywatny charakter zbiorów miał niewątpliwie wpływ na dostęp do bibliotek. Nierzadko były one zamknięte na cztery spusty, broniły się przed jakimikolwiek czytelnikami. Niektórzy właściciele starali się jednak

18 J. Vorstius, S. Joost, dz. cyt., s. 65. 
udostępniać swoje skarby, choć ograniczali krąg użytkowników do wąskiej grupy swoich urzędników, a korzystanie ze zbiorów uzależniali od specjalnej zgody (m.in. Gera, Ratyzbona, Zeil). Nawet jednak jeżeli zainteresowanym udało się zdobyć pozwolenie, problemem był krótki czas otwarcia bibliotek - zazwyczaj kilka godzin dziennie, rzadziej codziennie (Wertheim, Rossla, Maihningen). Korzystanie ze zbiorów ograniczał niekompletny stan katalogów, a nawet ich brak (Liebstein). Jeśli znajdowały się one w bibliotece, były to zazwyczaj katalogi alfabetyczne i/lub rzeczowe ${ }^{19}$.

\section{Model kariery zawodowej w bibliotece}

Model kariery zawodowej bibliotekarzy prywatnych zależał poniekąd od charakteru miejsca, w której pracowali. Regułą był nieliczny, aczkolwiek bogaty, księgozbiór i jednoosobowy personel - zob. Tabela 2. Od tej normy odbiegały jedynie Biblioteka Sekundogenituralna w Dreźnie i Królewska Biblioteka Podręczna w Stuttgarcie, zatrudniające po dwóch bibliotekarzy, co było rezultatem ich odpowiednio wysokiego budżetu, a także liberalniejszego nastawienia względem użytkowników. Konsekwencją tego stanu rzeczy był zarazem bardzo ograniczony ruch kadrowy. Wymiana personelu następowała głównie wskutek śmierci lub zmiany miejsca pracy bibliotekarza. Ten pierwszy przypadek miał miejsce częściej w bibliotekach arystokratów. Nie znaczy to, że i tam nie dochodziło do dobrowolnych rezygnacji z kariery bibliotekarskiej. Otto von Klump, dyrektor Biblioteki Podręcznej w Stuttgarcie, porzucił ją i wszedł na drogę kariery urzędniczej, gdy otrzymał awans na radcę dworu $\mathrm{w}$ wirtemberskim ministerstwie spraw zagranicznych ${ }^{20}$. Jeszcze inaczej potoczyły się losy Franza von Dingelstedta (bibliotekarz króla Wirtembergii), który wyjechał do Wiednia i tam zdobył laury jako reżyser i dyrektor teatru ${ }^{21}$. Na 43 bibliotekarzy aż 32 zadowoliło się pracą w jednej bibliotece.

O tym, że biblioteki prywatne nie były zamkniętym mikroświatem, świadczą przemieszczenia bibliotekarzy. Miały one charakter dwukierunkowy. Do bibliotek prywatnych napływali pracownicy z książnic uniwersyteckich (Eduard Jacobs, Hoffmann von Fallersleben), bibliotek miejskich (Albrecht Christoph Kayser) oraz publicznych bibliotek książęcych i królewskich (Joachim Marquardt, Ernst Förstemann). W odwrotnym kierunku

19 Zob. J. Petzholdt, Adressbuch der Bibliotheken Deutschlands...; P. Schwenke, dz. cyt.; W. Gröpler, Büchereien mittelbarer Fürsten und Grafen...

20 Zob. K. Bader, dz. cyt., s. 130.

21 Zob. Lexikon des gesamten Buchwesens, Bd. 2: Buck-Foster, hrsg. von S. Corsten, G. Pflug, F.A. Schmidt-Künsemüller, Stuttgart 1989, s. 299. 
podążyli Karl Dietrich Hülmann i Jakub Grimm. Pierwszy bezpośrednio z biblioteki uniwersyteckiej w Bonn przez Bibliotekę Dworską w Kassel do biblioteki uniwersyteckiej w Getyndze. J. Grimm rozpoczął swoją karierę bibliotekarską jako prywatny bibliotekarz króla Westfalii Hieronima.

Zatrudnienie w bibliotece stwarzało możliwości dalszej kariery urzędniczej. Tak było w przypadku Johanna Georga Theodora Graesse, który z pracownika prywatnej biblioteki w Dreźnie został awansowany na dyrektora zbiorów numizmatycznych. Bardziej typowe było jednak łączenie pracy w bibliotece prywatnej z zatrudnieniem w innej książnicy. Równocześnie bibliotekarzem Królewskiej Biblioteki Publicznej w Dreźnie oraz Królewskiej Biblioteki Prywatnej Króla Saksonii był Karl Christian Theodor Hempel ${ }^{22}$. Palma pierwszeństwa w tym zakresie należy się J. Petzholdtowi. Oprócz pracy w Bibliotece Sekundogenituralnej (1839-1887), będącej jego macierzystą instytucją, opiekował się od 1842 r. biblioteką małżonki następcy tronu Johanna, a od 1853 r. - biblioteką księcia Alberta. Ponadto przez rok zarządzał biblioteką drezdeńskiego Stowarzyszenia Rzemieślniczego ${ }^{23}$. Jeśli się zważy na jego rozległą działalność twórczą oraz fakt, że wychował samotnie dziesięcioro dzieci, tym bardziej imponują jego osiągnięcia zawodowe.

Tabela 2. Status zawodowy bibliotekarzy bibliotek prywatnych na ziemiach niemieckich w XIX w.

\begin{tabular}{|l|l|l|}
\hline Lp. & Nazwa biblioteki & Bibliotekarz/zawód \\
\hline 1. & $\begin{array}{l}\text { Fürstlich Hohenlohe-Bartenstein'sche, } \\
\text { Bartenstein, Wirtembergia }\end{array}$ & urzędnik kancelarii \\
\hline 2. & $\begin{array}{l}\text { Fürstlich Isenburg- Birstein'sche Bibliothek, } \\
\text { Birstein, Hesja-Nassau }\end{array}$ & bibliotekarz \\
\hline 3. & $\begin{array}{l}\text { Fürstlich Isenburgische Schlossbibliothek, } \\
\text { Büdungen, Hesja }\end{array}$ & urzędnik kancelarii \\
\hline 4. & $\begin{array}{l}\text { Gräfliche von Schweinitz'sche } \\
\text { Majoratsbibliothek, Dieban (Dziewin) k. Steinau } \\
\text { (Ścinawa), Śląsk }\end{array}$ & bibliotekarz \\
\hline 5. & $\begin{array}{l}\text { Fürstlich Fürstenbergische Hofbibliothek, } \\
\text { Donaueschingen, Badenia }\end{array}$ & $\begin{array}{l}\text { archiwariusz ksią- } \\
\text { żęcy }\end{array}$ \\
\hline 6. & $\begin{array}{l}\text { Privatbibliothek Sr. Maj. des Königs Albert, } \\
\text { Drezno, Saksonia }\end{array}$ & nauczyciel \\
\hline 7. & $\begin{array}{l}\text { Prinzliche Sekundogeniturbibliothek, Drezno } \\
\text { Biblioteka (Sekundogenituralna) Książęca], } \\
\text { Drezno, Saksonia }\end{array}$ & bibliotekarz \\
\hline
\end{tabular}

22 Zob. Tamże, s. 101.

${ }_{23}$ Zob. M. Mühlner, J. Petzholdt, Wegbereiter für Bibliographie und Bibliothekswesen im 19. Jahrhundert, Leipzig 1987, s. 16. 
Uczeni, poeci i inni - bibliotekarze bibliotek prywatnych (książąt, hrabiów, baronów)...

\begin{tabular}{|c|c|c|}
\hline 8. & $\begin{array}{l}\text { Reichsgräflich Schaffgotsch'sche Bibliothek, } \\
\text { Książ, Sląsk }\end{array}$ & bibliotekarz \\
\hline 9. & $\begin{array}{l}\text { Gräflich Erbach-Fürstenau'sche Bibliothek, } \\
\text { Fuerstenau bei Michelstadt, Hesja }\end{array}$ & nauczyciel \\
\hline 10. & $\begin{array}{l}\text { Reichsgräflich von Hochberg'sche Majorats- } \\
\text {-Bibliothek, Fuerstenstein (Książ), Śląsk }\end{array}$ & bibliotekarz \\
\hline 11. & Fürstlich Reuss Schlossbibliothek, Gera, Reuss & kwestor \\
\hline 12. & $\begin{array}{l}\text { Gräflich Oppersdorf'sche Bibliothek, Głogówek, } \\
\text { Śląsk }\end{array}$ & brak bibliotekarza \\
\hline 13. & $\begin{array}{l}\text { Gräflich von Mirbach'sche Fideikomiss- } \\
\text {-Bibliothek, Harff, Nadrenia }\end{array}$ & sekretarz hrabiego \\
\hline 14. & $\begin{array}{l}\text { Fürstlich Carolath-Beuthener Majoratsbibliothek, } \\
\text { Carolath (Siedlisko) k. Nowej Soli, Śląsk }\end{array}$ & $\begin{array}{l}\text { książęcy urzędnik } \\
\text { kancelaryjny }\end{array}$ \\
\hline 15. & $\begin{array}{l}\text { Fürstliche Bibliothek, Korvey, Biblioteka } \\
\text { prywatna Księcia von Ratibor }\end{array}$ & $\begin{array}{l}\text { książęcy urzędnik } \\
\text { kancelaryjny/poeta }\end{array}$ \\
\hline 16. & $\begin{array}{l}\text { Gräflich Wallenrodt'sche Bibliothek, Königsberg, } \\
\text { Prusy }\end{array}$ & $\begin{array}{l}\text { bibliotekarz } \\
\text { (I kustosz Biblioteki } \\
\text { Uniwersyteckiej } \\
\text { i Królewskiej } \\
\text { w Königsberg) } \\
\end{array}$ \\
\hline 17. & Herzogliche Schloss-Bibliothek, Koethen, Anhalt & bibliotekarz \\
\hline 18. & $\begin{array}{l}\text { Bibliotheca Carlowitziana, Kukustein } \\
\text { k. Liebstadt, Saksonia }\end{array}$ & właściciel biblioteki \\
\hline 19. & $\begin{array}{l}\text { Gräflich Solms-Laubachische Bibliothek, } \\
\text { Laubach, Hesja }\end{array}$ & nauczyciel \\
\hline 20. & $\begin{array}{l}\text { Reichsgräflich von Wolkenstein-Nostiz'sche } \\
\text { Bibliothek, Lobris (Luboradz) k. Jawora, Śląsk }\end{array}$ & duchowny \\
\hline 21. & $\begin{array}{l}\text { Fürstlich Oettingen-Wallerstein'sche } \\
\text { Fideikomissbibliothek, Maihingen, Bawaria }\end{array}$ & bibliotekarz \\
\hline 22. & Schlossbibliothek, Nieder-Schoenbrunn, Śląsk & duchowny \\
\hline 23. & $\begin{array}{l}\text { Gräflich Esterházy’sche Schlossbibliothek, } \\
\text { Nordkirchen, Westfalia }\end{array}$ & brak danych \\
\hline 24. & Fürstlich Wiedische Bibliothek, Noerdlingen & marszałek dworu \\
\hline 25. & $\begin{array}{l}\text { Gräflich von Fürstenbergische Bibliothek, } \\
\text { Oberhundem, Westfalia }\end{array}$ & nauczyciel \\
\hline 26. & Grossherzogliche Privatbibliothek, Oldenburg & urzędnik kancelarii \\
\hline 27. & $\begin{array}{l}\text { Freiherrlich von Oldershausen'sche } \\
\text { Majoratsbibliothek, Oldershausen, Hannover }\end{array}$ & brak danych \\
\hline 28. & $\begin{array}{l}\text { Fürstlich Hohenlohe'sche Bibliothek, Oppurg, } \\
\text { Saksonia-Weimar }\end{array}$ & kwestor \\
\hline
\end{tabular}

${ }^{24}$ Zob. P. Schwenke, dz. cyt., s. 211. 


\begin{tabular}{|c|c|c|}
\hline 29. & $\begin{array}{l}\text { Gräflich Schönborn-Wiesentheid'sche Bibliothek, } \\
\text { Pommersfelden, Bawaria }\end{array}$ & duchowny \\
\hline 30. & Schlossbibliothek, Pless (Pszczyna), Śląsk & brak danych \\
\hline 31. & $\begin{array}{l}\text { Gräflich Baudissin'sche Fideikommissbibliothek, } \\
\text { Rantzau, Szlezwik-Holsztyn }\end{array}$ & inspektor dóbr \\
\hline 32. & $\begin{array}{l}\text { Fürstlich Thurn- und Taxis'sche Hofbibliothek, } \\
\text { Ratyzbona, Bawaria }\end{array}$ & archiwariusz \\
\hline 33. & $\begin{array}{l}\text { Freiherrlich Schenk von Stauffenberg'sche } \\
\text { Familienbibliothek, Risstissen, Wirtembergia }\end{array}$ & brak danych \\
\hline 34. & $\begin{array}{l}\text { Freiherrlich von Frieseen'sche } \\
\text { Familienbibliothek, Roetha, Saksonia }\end{array}$ & brak danych \\
\hline 35. & $\begin{array}{l}\text { Gräflich Stolbergische Hausfbibliothek, Rossla, } \\
\text { Saksonia }\end{array}$ & kwestor \\
\hline 36. & $\begin{array}{l}\text { Reichsgräfliche Grote'sche } \\
\text { Fideikommissbibliothek, Schauen, Saksonia }\end{array}$ & właściciel \\
\hline 37. & Schlossbibliothek, Schillingsfürst, Bawaria & urzędnik kancelarii \\
\hline 38. & $\begin{array}{l}\text { Herrschaftlich von Zehmen'sche Bibliothek, } \\
\text { Schleinitz, Saksonia }\end{array}$ & brak danych \\
\hline 39. & $\begin{array}{l}\text { Gräflich Erbach-Schönberg'sche } \\
\text { Familienbibliothek, Schoenberg, Hesja }\end{array}$ & brak danych \\
\hline 40. & $\begin{array}{l}\text { Fürstliche Hohenzollerische Hofbibliothek, } \\
\text { Sigmaringen, Prusy }\end{array}$ & dyrektor muzeum \\
\hline 41. & $\begin{array}{l}\text { Freiherrlich von Landsberg'sche Bibliothek, } \\
\text { Steinfurt, Westfalia }\end{array}$ & brak danych \\
\hline 42. & $\begin{array}{l}\text { Gräflich Stolberg-Stolberg'sche Bibliothek, } \\
\text { Stolberg, Saksonia }\end{array}$ & duchowny \\
\hline 43. & $\begin{array}{l}\text { Königliche Handbibliothek, Stuttgart, } \\
\text { Wirtembergia }\end{array}$ & $\begin{array}{l}\text { dyrektor bibliote- } \\
\text { ki - radca dworu } \\
\text { (Edmund Zoller) }\end{array}$ \\
\hline 44. & $\begin{array}{l}\text { Gräflich Giesch’sche Bibliothek, Thurnau, } \\
\text { Bawaria }\end{array}$ & urzędnik kancelarii \\
\hline 45. & $\begin{array}{l}\text { Fürstlich Löwenstein-Wertheim- } \\
\text { Freudenbergische Bibliothek, Triefenstein, } \\
\text { Bawaria }\end{array}$ & $\begin{array}{l}\text { biblioteka nieupo- } \\
\text { rządkowana, zbiory } \\
\text { nieopracowane }{ }^{25} \\
\end{array}$ \\
\hline 46. & $\begin{array}{l}\text { Freiherrlich von Wolff-Metternich'sche } \\
\text { Bibliothek, Wehrden, Westfalia }\end{array}$ & brak danych \\
\hline 47. & $\begin{array}{l}\text { Fürstlich Stolberg-Wernigerödische Bibliothek, } \\
\text { Wernigerode, Saksonia }\end{array}$ & archiwariusz \\
\hline 48. & $\begin{array}{l}\text { Fürstlich Löwenstein-Wertheim-Rosenbergische } \\
\text { Domänenkanzlei-Bibliothek, Wertheim, Badenia }\end{array}$ & archiwariusz \\
\hline
\end{tabular}

25 Zob. tamże, s. 349. 
Uczeni, poeci i inni - bibliotekarze bibliotek prywatnych (książąt, hrabiów, baronów)...

\begin{tabular}{|l|l|l|}
\hline 49. & $\begin{array}{l}\text { Königliche Schlossbibliothek, Wilhelmshoehe, } \\
\text { Hesja-Nassau }\end{array}$ & uczony \\
\hline 50. & $\begin{array}{l}\text { Fürstlich Waldburg-Wolfegg-Waldsee'sche } \\
\text { Bibliothek, Wolfegg, Wirtembergia }\end{array}$ & właściciel \\
\hline 51. & Fürstliche Bibliothek, Wurzach, Wirtembergia & brak bibliotekarza \\
\hline 52. & $\begin{array}{l}\text { Von Brand-Wutzig-Hermsdort'sche Familien- } \\
\text { Fideikommissbibliothek, Wutzig, Brandenburgia }\end{array}$ & brak danych \\
\hline 53. & $\begin{array}{l}\text { Fürstlich Waldburg-Zeil-Trauchburg'sche } \\
\text { Fideikommissbibliothek, Zeil, Wirtembergia }\end{array}$ & $\begin{array}{l}\text { prywatny sekretarz } \\
\text { książęcy }\end{array}$ \\
\hline 54. & Schlossbibliothek, Sagan (Żagań), Śląsk & brak danych \\
\hline
\end{tabular}

Źródło: J. Petzholdt, Adressbuch der Bibliotheken Deutschlands mit Einschluss Österreich und der Schweiz, Dresden 1875; P. Schwenke, Adressbuch der deutschen Bibliotheken, Leipzig 1893; W. Gröpler, Büchereien mittelbarer Fürsten und Grafen Deutschlands und Österreichs sowie ehemaliger freien Deutschen Reichsstädte, Leipzig 1891.

\section{Staż pracy}

Zbiorowość bibliotekarzy prywatnych kolekcji była przywiązana do swojego miejsca zatrudnienia. Można to stwierdzić jednoznacznie na podstawie analizy czasu pracy poszczególnych jej członków. Ponad połowa z nich (23 osoby) przepracowała w bibliotece ponad dziesięć lat, z tego jedenastu mieści się w przedziale 11-20 lat, a siedmiu - w przedziale 21-30 lat. Nie warto wyprowadzać tym razem wniosków wynikających z rozkładu terytorialnego - ze względu na fragmentaryczność danych. Przywiązanie to nie miało charakteru sentymentalnego. Biblioteka prywatna nęciła swoim księgozbiorem jako potencjalnym warsztatem działalności naukowej lub literackiej. Z pewnością nie można jednak tego powiedzieć ani o J. Petzholdtcie, ani o A.Ch. Kayserze i J.G.T. Graessem. Są to jednak wyjątki. Należy to mieć na uwadze przy analizie wieku rozpoczęcia aktywności zawodowej. $\mathrm{W}$ bibliotece prywatnej przeważali - wbrew pozorom - ludzie młodzi. Na starość szukały zaś w niej schronienia osoby z już bogatym bagażem doświadczeń życiowych i zawodowych. W przypadku Hoffmanna von Fallersleben posada bibliotekarska w Korvey, jakkolwiek miał już za sobą staż biblioteczny we Wrocławiu, była zwykłą synekurą. Dla Eduarda Adolfa Jacobiego roczna praca na zamku we Friedenstein w Gotha (1861-1862), podobnie jak wcześniejsze dwuletnie zatrudnienie w getyńskiej bibliotece uniwersyteckiej (1817-1819), była tylko mało istotnym epizodem ${ }^{26}$. Abstrahując od motywacji skłaniających do pracy w bibliotece, trzeba chylić czoła przed takimi bibliotekarzami jak np. Eduard Jacobs (1866-1917) ${ }^{27}$,

\footnotetext{
26 Zob. K. Bader, dz. cyt., s. 116.

27 Zob. tamże, s. 116-117.
} 
J. Marquardt (1855-1883) ${ }^{28}$, Karl Friedrich Kielmeyer (1816-1844) ${ }^{29}$, którzy wytrwali na bibliotecznym posterunku do końca swoich dni. Na miano weteranów zasługują zwłaszcza E. Jacobs i J. Petzholdt. Kariera obu trwała niemal pół wieku: Petzholdta - 48 lat, a Jacobsa - 51 lat.

\section{Wykształcenie}

Stosownie do niewielkiej liczby omawianego typu bibliotek prywatnych mało było również pracujących w nich bibliotekarzy. Wspomniane wyżej źródła wymieniają 43 osoby, które bądź całkowicie, bądź częściowo poświęciły się pracy w bibliotece. Nie są to liczby szczególnie imponujące. $Z$ wielu względów grupa ta zasługuje jednak na osobne omówienie. Bibliotekarze ci należeli niewątpliwie do ówczesnej elity intelektualnej. Wszyscy, bez wyjątku, byli osobami wykształconymi. Najliczniejszą grupę wśród badanej zbiorowości stanowili absolwenci studiów teologicznych, następnie - prawnicy. Niewielu, w porównaniu z sytuacją panującą w bibliotekach uniwersyteckich czy dworskich bibliotek publicznych, było wśród nich historyków i filologów. Generalnie jednak personel bibliotek prywatnych rekrutował się spośród absolwentów studiów humanistycznych, co wskazuje również na charakter obejmowanych przez nich księgozbiorów. Zważywszy na to, że nie dysponujemy kompletnymi danymi o personelu poszczególnych bibliotek, z pewną ostrożnością trzeba się wypowiadać o preferencjach dotyczących wykształcenia zatrudnianych bibliotekarzy. Znamienne były z pewnością upodobania Ratyzbony czy Weimaru do historyków, Friedenstein - do filozofów, Stuttgartu - do prawników, a Korvey i Laubach - do filozofów.

\section{Zawód/zajęcie}

Do protoplastów zawodowych bibliotekarzy fachowych (berufliche Fachbibliothekare) należeli przede wszystkim bibliotekarze królów, książąt i hrabiów, nie w każdym wszak wypadku. Tacy bibliotekarze jak J. Petzholdt (Drezno), H. von Fallersleben (Korvey) czy J. Grimm (Wilhelmshöhe) nie pracowali nigdzie poza biblioteką, ale też nie była ona wyłącznym źródłem ich utrzymania. Przeciwnie, raczej stanowiła dopełnienie ich działalności twórczej, naukowej bądź literackiej. Wielu pracowników bibliotek prywatnych zajmowało posadę nauczyciela gimnazjalnego lub duchownego. Dotyczy to głównie bibliotek fundacyjnych. Wzmiankowany J. Marquardt miał za sobą nawet długoletnią karierę profesorską w Berlinie i Gdańsku, a następnie - dyrektorską w Poznaniu, by ostatecznie objąć posadę dyrektora

$\begin{array}{ll}28 & \text { Zob. tamże, s. } 160 . \\ 29 & \text { Zob. tamże, s. } 125 .\end{array}$ 
Gimnasium Illustre w Gotha ${ }^{30}$. Relatywnie dużo nauczycieli akademickich godziło swoje główne zajęcie z pracą w bibliotece prywatnej. Nie ma w tym nic zaskakującego, gdyż chodzi o osoby wywodzące się z Frankfurtu nad Odrą, Giessen i Lipska, a zatem z ośrodków akademickich. Profesorem we Frankfurcie nad Odrą był Karl Dietrich Hüllmann. W 1811 r. wraz z całym uniwersytetem przeniósł się do Wrocławia. Zanim został bibliotekarzem w Stuttgarcie, K.F. Kielmeyer w latach 1796-1816 wykładał na uniwersytecie w Tybindze. K.D. Hüllmann na uniwersytet ponownie trafił w Bonn, gdzie w 1818 r. został mianowany rektorem. Burzliwa, jak całe jego życie, była kariera akademicka H. von Fallerslebena ${ }^{31}$. Od 1835 r., tj. przed zatrudnieniem w Korvey, prowadził on wykłady z języka niemieckiego na uniwersytecie Wrocławskim, by zrzec się tej posady w $1842 \mathrm{r}$. z powodów politycznych $^{32}$. W przypadku pracowników bibliotek prywatnych pełnienie obowiązków bibliotekarskich było jednak na ogół zajęciem ubocznym ( $\mathrm{Ne}$ benamt), podczas gdy ich główną powinność (Hauptamt) stanowiło służenie hrabiemu, księciu jako urzędnik na dworze ${ }^{33}$.

\section{Praca naukowa}

Praca naukowa była naturalnym żywiołem bibliotekarzy bibliotek prywatnych, i to nie tylko tych $\mathrm{z}$ tytułem profesorskim. Niewątpliwie ułatwiały im to bardzo bogate, a przede wszystkim obfitujące w liczne zabytki piśmiennictwa niemieckiego księgozbiory. Zrozumiała jest zatem supremacja filologów i historyków. Stosunkowo wielu z nich zdobyło tytuły naukowe i splendor. O H. von Fallerslebenie i jego osiągnięciach była mowa już wcześniej. Złotymi zgłoskami w dziedzinie filologii zapisali się też J.G.T. Graesse, prywatny bibliotekarz króla Saksonii. Wielkie uznanie w Niemczech i za granicą przyniósł Graessemu podręcznik historii literatury powszechnej ${ }^{34}$. Johann Peter Eckermann zyskał światową sławę dzięki swoim Gespräche mit Goethe in den letzten Jahren seines Lebens... ${ }^{35} \mathrm{Od} 1823 \mathrm{r}$. był on

30 Zob. Tamże, s. 160.

31 Droga życiowa i zawodowa H. von Fallerslebena wiodła z Korvey (miejsce urodzenia) przez Helmstedt (gimnazjum), Brunszwik (studia) do Wrocławia (praca w bibliotece uniwersyteckiej oraz posada wykładowcy języka niemieckiego i literatury w tamtejszym uniwersytecie), by osiągnąć kres w rodzinnej miejscowości - zob. A. Elschenbroich, Hoffmann von Fallersleben, Heinrich, [w:] Neue Deutsche Biographie 1972, Bd. 9, s. 421-423.

32 Zob. tamże, s. 110.

33 Zob. Z. Gębołyś, Zawód bibliotekarski na ziemiach niemieckich w latach 1789-1871. Teoria i praktyka. Katowice 2002.

34 Zob. J.G.T. Graesse, Lehrbuch einer allgemeinen Literärgeschichte aller bekannten Völker der Welt: von der ältesten bis auf die neueste Zeit, Bd. 4, Dresden 1837-1859.

35 Zob. np. wydanie z początku XX w.: J. P. Eckermann, Gespräche mit Goethe in den letzten Jahren seines Lebens 1823-1822, hrsg. M. Jacobs, Leipzig 1929. 
pomocnikiem literackim wielkiego poety. Najwybitniejszym historykiem pośród bibliotekarzy prywatnych był J. Marquardt, zarządca książęcych zbiorów sztuki i nauki na zamku Friedenstein. Badacz kontynuował dzieło Wilhelma Adolfa Beckera o życiu starożytnych Rzymian ${ }^{36}$. Był uznawany za wybitnego znawcę historii starożytnego Rzymu. Szanowanymi uczonymi na polu nauk przyrodniczych byli natomiast Friedrich August Benjamin Puchelt i Gustav Kunze z Lipska oraz K.F. Kielmeyer ze Stuttgartu.

Określanie bibliotekarzy prywatnych mianem Dichterbibliothekare nie jest wcale przesadne, jeśli się zważy na to, że aż dziesięciu z nich parało się twórczością literacką. Sześciu bibliotekarzy, tj. Franz Dingelstedt, Karl von Heigel, H. von Fallersleben i Heinrich Konrad Föringer (Monachium) to właśnie klasyczni Dichterbibliothekare, bowiem uprawiali poezję. $\mathrm{K}$. von Heigel był równocześnie autorem romansów i pisarzem dramatycznym $^{37}$. Niestety, niewiele można powiedzieć o ich działalności bibliotekarskiej. Fakt, że nie pozostawili po sobie żadnych dzieł pisanych, a bibliotekarska literatura fachowa też o nich nie wspomina, każe przypuszczać, iż nie wsławili się niczym szczególnym. Pracownikami bibliotek prywatnych byli też - choć sporadycznie - duchowni, lekarze, dziennikarze, wreszcie urzędnicy dworscy. Karl Egon Ebert, bibliotekarz księcia elektora von Fürstenberg, był ceniony w świecie literackim jako autor ballad oraz dramatopisarz.

\section{Działalność naukowa na polu bibliotekarstwa}

Wkład bibliotekarzy bibliotek prywatnych w bibliotekoznawczą literaturę fachową w XIX w. jest w sensie ilościowym marginalny (zaledwie czterech autorów), za to bardzo ważny, gdy chodzi o znaczenie ich dzieł dla teorii i praktyki bibliotekarskiej. Listę piszących na tematy bibliotekarskie rozpoczyna A.Ch. Kayser. Jego dzieło Ueber die Manipulation bey der Einrichtung einer Bibliothek und der Verfertigung der Bücherverzeichnisse... (Bayreuth 1790), wychwalane zresztą bardzo przez F.A. Eberta, wywarło ogromny wpływ na ówczesną teorię bibliotekarską, szczególnie w zakresie katalogowania alfabetycznego i rzeczowego. Problematyką bibliotekarską zajmował się też J.G.T. Graesse. W jednym z najstarszych czasopism bibliotekarskich „Serapeum. Zeitschrift für Bibliothekwissenschaft, Handschriftenkunde und ältere Litteratur" opublikował kilka artykułów na temat historii bibliotek Francji, Danii i Holandii. Recenzował tam też wykazy rękopisów i inkunabułów. Podstawowym żywiołem pracy naukowej Graessego była bibliografia. Nie ograniczał się on do opisywania i omawiania dokonań innych. W 1843 r. wydał bibliografię najważniej-

${ }^{36}$ Zob. W.A. Becker, Charikles, Bilder altgriechischer Sitte, Teil 1-2, Leipzig 1840.

37 Zob. Lexikon des gesamten Buchwesens..., s. 299. 
szych dzieł na temat wiary w czarownice, cuda, duchy i inne zabobony ${ }^{38}$. W 1845 r. opublikował wykaz najważniejszych dzieł dotyczących duszy ludzkiej i „Zwierzęcej” oraz nieśmiertelności ${ }^{39}$. Ponadto niesamoistne prace bibliograficzne tego bibliotekarza można znaleźć w wielu naukowych rozprawach. Jednak najważniejszym jego dziełem bibliograficznym jest Tresor de livres rares et precieux..., wydany w Dreźnie w latach $1859-1869^{40}$. Koncepcją nawiązał Graesse do dzieła francuskiego bibliografa i księgarza Jacquesa Charlesa Bruneta $(1780-1867)^{41}$. Zebrał mianowicie informacje o rzadkich, naukowo wartościowych i wybitnych, drogich i kosztownych (przez zasięg i wyposażenie) oraz poszukiwanych przez bibliofilów księgach ${ }^{42}$. Bez wątpienia najwybitniejszym obok F.A. Eberta, a $\mathrm{z}$ całą pewnością - najpłodniejszym na polu bibliotekarstwa był J. Petzholdt. W autobiografii z 1863 r. wymienia 127 większych i mniejszych prac, pomija przy tym wiele drobniejszych artykułów i recenzji ${ }^{43}$. Przyszła, kompletna bibliografia jego prac, uwzględniająca zarówno dzieła opublikowane w następnym okresie (1864-1891), jak i pochodzące $\mathrm{z}$ poprzednich lat, nieujęte $\mathrm{w}$ wykazie, powinna liczyć co najmniej kilka razy więcej pozycji. Domeną studiów naukowych J. Petzholdta były bibliotekarstwo i bibliografia. W obrębie tego pierwszego obszaru zapisał się on jako wydawca czasopisma bibliotekarsko-bibliograficznego „Neuer Anzeiger für Bibliographie und Bibliothekswissenschaft” Dresden-Stuttgart $^{44}$, następnie jako autor ksiąg adresowych bibliotek niemieckich (1844,

38 Zob. J.G.T. Graesse, Bibliotheca magica et pneumatica oder Wissenschaftlich geordnete Bibliographie der wichtigsten in das Gebiet des Zauber-, Wunder-, Geister- und sonstigen Aberglaubens vorzüglich älterer Zeit einschlagenden Werke, Leipzig 1843.

39 Zob. tenże, Bibliotheca Psychologica oder Verzeichniss der wichtigsten über das Wesen der Menschen- und Thierseelen und die Unsterblichkeitslehre handelnden Schriftsteller älterer und neuerer Zeit, Leipzig 1845.

40 Zob. tenże, Trésor de livres rares et précieux ou Nouveau dictionaire bibliographique contenant plus de 1000000 articles de livres rares, curieux et recherchés, d'ouvrages de luxe, etc. avec les signes connus pour distinguer les éditions originales des contrefaçons qui en ont été faites, des notes sur la rareté et le mérite des livres cités et les prix que ces livres ont atteints dans les ventes les plus fameuses, et qui 'ls conservent encore dans les magasins des bouquinistes les plus renommés de l'Europe, Bd. 1-8, Berlin 1922.

${ }^{41}$ Zob. J.Ch. Brunet, Manuel du libraire et de l'amateur de livres, cinquième éd. originale entièrement ref. et augm. d'un tiers par l'auteur, Paris 1860-1865.

${ }_{42}$ Zob. J. Jacob, Zum 175. Geburtstag von Johann Georg Theodor Graesse, „Zentralblatt für Bibliothekswesen“ 1989, s. 15, 18-20.

43 Zob. J. Petzholdt, Chronologische Übersicht von bibliographischen Systemen, „Neuer Anzeiger für Bibliographie und Bibliothekswissenschaft" 1860, s. 1-10, 33-38, 65-71, 101-108, 133-140, 165-173.

44 „Anzeiger für Literatur der Bibliothekswissenschaft” Dresden 1840-1844; „Anzeiger der Bibliothekswissenschaft”, Dresden-Halle 1845-1849; „Anzeiger der Bibliographie und Bibliothekswissenschaft”, Halle 1850-1855; „Neuer Anzeiger für Bibliographie und Bibliothekswissenschaft”, Dresden-Stuttgart 1856-1886. 
$1845,1848,1853,1875)$, wreszcie jako autor podręcznika bibliotekarskiego Katechismus der Bibliothekenlehre ${ }^{45}$. Mniejsze prace bibliograficzne J. Petzholdta można podzielić na cztery grupy. Pierwsza z nich ma za przedmiot biblioteki saksońskie. Drugą tworzą bibliografie, których powstanie pozostaje w bezpośrednim związku z zarządzanymi przez Petzholdta bibliotekami i ich zbiorami. Trzecia grupa obejmuje bibliografie osobowe, m.in. królów saksońskich. Ostatnią stanowią prace bibliograficzne inspirowane jubileuszami, np. bibliografia z okazji jubileuszu Szekspira ${ }^{46}$. Do grona znawców bibliotek i ich zbiorów należy zaliczyć niewątpliwie E. Förstemanna, który pozostawił po sobie drukowane opisy Biblioteki Hrabiowskiej w Wernigerode oraz Królewskiej Biblioteki Publicznej w Dreźnie. Godnym wspomnienia autorem jest także E. Zoller, w latach 1889-1899 kierujący Königliche Handbibliothek w Stuttgarcie. Jego rozprawa bibliotekarska z 1846 r. pt. Die Bibliothekswissenschaft im Umrisse ${ }^{47}$ uchodzi za najwartościowsze po rozprawie J. Petzholdta ówczesne dzieło z zakresu bibliotekoznawstwa.

\section{Zakończenie}

Analiza profesjologiczna środowiska bibliotekarzy pewnego typu bibliotek prywatnych na ziemiach niemieckich w XIX w. miała na celu ukazanie wielostronności zainteresowań naukowych, zawodowych, a także bogactwa charakterów, karier bibliotekarskich. Czas, na który przypadł ich mariaż z biblioteką, był przełomowy z wielu względów. Przełom wieków XVIII i XIX oraz całe dziewiętnaste stulecie to burzliwy okres w dziejach bibliotek. Praca w pomnażającej swoje zbiory książnicy, coraz szerzej dostępnej dla czytelników, w coraz większym stopniu zmuszonej zaspokajać silniej różnicujące się potrzeby czytelników, przestaje być cichym i spokojnym zajęciem. Strażnik czy sługa? Tak zatytułował rozprawę na temat bibliotekarzy Gottfried Rost ${ }^{48}$. Jest ona ze wszech miar trafna w odniesieniu do przeobrażeń zachodzących w bibliotekarstwie dziewiętnastowiecznym. Ówczesny bibliotekarz to osoba znajdująca się na swoistym rozdrożu. Rola strażnika zbiorów zaczyna powoli odchodzić bezpowrotnie do przeszłości, kłóci się z wyzwaniami czasu i stanowiącymi odpowiedź na nie zadaniami biblioteki. Od bibliotekarza współczesny mu czytelnik oczekiwał dostarczenia naukowej strawy w większej ilości, większym wyborze, w bardziej dogodnych warunkach,

${ }^{45}$ Zob. J. Petzholdt, Katechismus der Bibliothekenlehre: Anleitung zur Einrichtung und Verwaltung von Bibliotheken, Leipzig 1856.

46 Zob. M. Mühlner, dz. cyt., s. 33-35.

47 Zob. E. Zoller, Die Bibliothekswissenschaft im Umrisse, Stuttgart 1846.

48 Zob. G. Rost, Der Bibliothekar. Schatzkämmerer oder Futterknecht?, Leipzig 1990. 
a także poinformowania o pozycjach poprzez bardziej przejrzysty niż dotychczas aparat informacyjny w postaci katalogów. W kontekście kształtowania się nowego, samodzielnego oblicza zawodu bibliotekarza związek ten nierzadko prowadził do nieuchronnych spięć i konfliktów. Wnioski poczynione w tej analizie można uczynić pełniejszymi poprzez badanie środowiska bibliotekarzy bibliotek prywatnych na ziemiach niemieckich.

\section{Streszczenie}

Biblioteki książąt, margrabiów i hrabiów niemieckich zaczęły powstawać w XVI w. Ich rozkwit datowany jest na wiek XVIII i XIX. Jako typ bibliotek prywatnych odznaczały się dużym zróżnicowaniem. Z wyjątkami - należały do księgozbiorów małej i średniej wielkości. Na tle innych bibliotek wyróżniały się jednak bardzo cennymi kolekcjami rękopisów, inkunabułów i starodruków. Autor artykułu dokonał socjologicznej charakterystyki bibliotekarzy pracujących w bibliotekach tego rodzaju. W szczególności omówił ich wykształcenie i kwalifikacje naukowe. Zarysowany został również model kariery zawodowej bibliotekarzy. Zwrócono też uwagę na strukturę zatrudnienia personelu $\mathrm{w}$ tych bibliotekach oraz na ruch kadrowy. Nakreślono również aktywność naukową pracowników w zakresie bibliotekarstwa.

Slowa kluczowe: biblioteki prywatne - bibliotekarze, Niemcy - XIX w. - zawód - wykształcenie - kwalifikacje naukowe - kwalifikacje bibliotekarskie - dzieła bibliotekarskie.

\section{Summary}

\section{The scientists, poets and the others - librarians of private libraries (princes, margraves and counts) in German territo- ries in XIX Century}

Libraries of princes, margraves and counts in Germany started their existence in the sixteenth century but their really blossomed as late as in the eighteenth and nineteenth centuries. As a distinctive type of private libraries they were largely diversified, however mainly they were small and medium-sized institutions, but consisted of valuable collections of manuscripts, incunabula and old prints. In the article Author provides an attempt to build a sociological characteristics of these private librarians, focusing specifically 
on their education, academic qualifications and professional careers. There is also presented the structure (and changes) of staff employment in the libraries as well as private librarians' research activity in the field of librarianship.

Key words: Private libraries - librarians - Germany - profession - education - scientific qualifications - library qualifications - works in the field of librarianship. 